\title{
Monetary Policy Transmission
}

\section{Mechanism in Fiji: An Empirical Analysis of The Quarterly Model}

\author{
T.K. Jayaraman \\ School of Economics, Faculty of Business and Economics \\ the University of the South Pacific, Laucala Bay Road, Suva, Fiji Islands. \\ Tel: +679-323-2178 E-mail: jayaraman_tk@usp.ac.fj \\ Chee-Keong Choong (Corresponding author) \\ Department of Economics, Faculty of Accountancy and Management \\ Universiti Tunku Abdul Rahman, Lot PT 21144 \\ Jalan Sungai Long, Bandar Sungai Long, Cheras, 43000 Kajang, Selangor D.E., Malaysia. \\ Tel: +603-9019-4772Ｅ-mail: choongck@mail.utar.edu.my
}

\begin{abstract}
Fiji's central bank, the Reserve Bank of Fiji (RBF) since its inception in 1983, has been pursuing monetary policy with the mandated objectives of economic growth with price stability and an adequate level of exchange reserves. In 1988, as part of financial sector reforms, RBF discontinued the use of direct instruments and switched on to employment of indirect instruments for influencing interest rates. For the past two decades, RBF has been conducting regular open market type operations in its own paper, known as RBF Notes for liquidity management. The yield to maturity of its 91-day RBF Notes determined through tender system, known as policy indicator rate (PIR) signals the monetary policy stance of RBF. This paper undertakes an empirical study of transmission mechanism of monetary policy over a 17-year period (1990Q1-2006Q4). Using variance decomposition and impulse response analysis, we find that money channel is the most important one amongst the four channels of transmission mechanism investigated.
\end{abstract}

Keywords: Monetary Policy, Transmission Mechanism, Structural VAR, Monetary Aggregates, Bank Credit, Fiji

\section{Introduction}

Among the 14 independent Pacific island countries (PICs), eight have been using the currencies of their former rulers, as legal tender ever since their political independence: Cook Islands and Niue (the New Zealand dollar); Kiribati, Nauru and Tuvalu (the Australian dollar); and Federated States of Micronesia, Palau and Republic of Marshall islands (the US dollar). The other six PICs namely, Fiji, Papua New Guinea (PNG), Samoa, Solomon Islands, Tonga and Vanuatu introduced their own currencies after their independence in the 1970s. While PNG shifted to a floating exchange rate regime in 1994, the other five countries continued to adopt some forms of fixed exchange rate regimes. The currencies of Fiji, Samoa and Vanuatu are pegged to a basket of currencies of their major trading partners, while the exchange rate regime of Solomon Islands is a crawling peg and the currency of Tonga has a peg within horizontal bands (Browne 2006). The tasks of exchange rate management together with maintenance of price stability through the formulation and implementation of monetary policies and their implementation are performed by their respective monetary authorities.

However, there is a paucity of studies on transmission mechanism of monetary policy in the Pacific island countries. Although Fiji's monetary policy received considerable attention from various authors (Rao and Singh 2006, Waqabaca 2000, Katafono 2000, Waqabaca and Morling 1991), their studies did not specifically focus on channels of transmission mechanism, as part of continuous investigation of what is inside the "black box" (Mishkin 2001). Accordingly, this paper has been motivated to undertake a more detailed analysis of monetary policy transmission mechanism in the island countries under fixed exchange rate regime by examining the case of Fiji.

The choice of Fiji is dictated by various factors. Aside from the availability of consistent time series of data, Fiji with private sector activities of some significance has, amongst PICs, relatively well-developed money and capital markets. Further, Fiji was the first among PICs to move away from quantitative controls on credit and interest rates, by switching 
to market based instruments of monetary policy as part of financial sector liberalisation and deregulation measures since 1988. Fiji's central bank's monetary policy framework now uses its own 91-day paper's yield to maturity rate, labeled as the policy indicator rate (PIR) as the main instrument to signal the stance of monetary policy. The changes in PIR are intended to influence the tightness or otherwise of money market conditions, and accordingly to determine the overnight inter-bank lending rate and the money market rates in general on all short term instruments.

The objective of the paper is to examine the links between PIR and the key outcomes including output growth and price level and investigate how fast and to what extent changes in the central bank's interest instrument impact output and inflation. The paper is organised on the following lines. The second section provides a brief literature survey; the third section reviews the monetary policy measures adopted in Fiji since the establishment of its monetary authority in 1983; the fourth section outlines the modeling procedure and methodology for the study; the fifth section presents the results and the sixth section provides a summary listing some conclusions with policy implications.

\section{Monetary Policy Transmission: A Brief Literature Survey}

Monetary policy is aimed at influencing interest rate and availability of loanable funds for investment through central bank's control of money supply. The process through which monetary policy decisions affect aggregate demand, gross domestic product (GDP) in real terms, and price level is described as monetary transmission (Meltzer 1995). The impact of monetary policy decision on the country's GDP domestic product is through its influences on consumption and investment decisions of households, business and financial intermediaries. Monetary transmission mechanism refers to the general conceptual framework, while the channel of monetary influences refers to "the route through which the monetary disturbances influence the goal variables" (Pierce and Tysome 1985: 22). Thus, by differentiating between a given transmission mechanism and a channel of monetary influence, the two authors indicated that it is possible for a number of channels of monetary influences to operate within the same transmission mechanism.

There are at least six channels through which monetary policy appears to be impacting economic activities (Mishkin 2006). These are: (i) interest rate channel; (ii) money supply channel; (iii) credit channel; (iv) balance-sheet channel; (v) asset price channel; (vi) exchange rate channel; and (vii) expectations channel. A stylized presentation (Figure 1) illustrates the channels of transmission mechanism (IMF 2004). One should however recognise these channels of transmission operate with varying lags depending on the levels of economic development in general.

\subsection{Interest Rate Channel}

The Keynesian view is that a fall in nominal interest rate, following a rise in nominal money stock, given the unchanged price level in the short run due to market rigidities, would cause rise in investment spending, thereby increasing aggregate demand and rise in output. The key point here is that it is the real rather than nominal rate that influences investment. Taylor (1995) in his survey on empirical research studies on interest rate channel concluded that there is strong empirical evidence for substantial effects on consumer spending on semi-durables and investment spending, making the interest rate monetary transmission mechanism a strong one.

\subsection{Money Supply Channel}

The money supply view takes the position that expansionary monetary policy increases bank reserves, thereby relaxing the constraints to banks' ability to create more loans. As a result, short-term interest rate falls. Thus, expansionary monetary policy, which lowers the short-term nominal interest rate, also lowers the short-term real interest rate, holding true in a world with rational expectations (Mishkin 1996). Here, money supply would mean either narrow money, M1 (comprising currency outside the banks and demand deposits) or broad money M2, (consisting of M1 and savings and time deposits).

\subsection{Credit Channel}

Even if investment is insensitive to interest rate, increase in money supply through rise in bank reserves steps up banks' ability to expand lending. Consequently, banks would make available loans to new borrowers as well, since most of the latter are dependent on bank loans. This would encourage further consumption spending in terms of purchases of semi-durable goods, which would lead to rise in GDP. The bank credit channel has assumed greater importance in recent years, not only in advanced but also in developing economies as documented by Bernanke (1986), Bernanke and Blinder (1988), Kashyap et al. (1993) and Kashyap and Stein (1994).

On the other hand, King (1986), Romer and Romer (1990), Ramsey (1993) and Guender (1998) questioned the strength of credit mechanism. Morris and Sellon (1995) who noted that money supply and interest rate channels are significant transmission channels, did not totally reject the role of bank credit. These apparent contradictions appear to have resulted from the difficulty in isolating the effect of monetary variables on output due to feedback effect from output to monetary variables.

\subsection{Balance Sheet Channel}

The balance sheet channel view lays emphasis on the role of collateral in reducing moral hazards. An expansionary monetary policy causes increases in financial and physical asset prices, thereby raising the market net worth of firms 
and the value of collateral, company cash flow and ultimately the firms' credit worthiness. Further, a rise in asset prices increases the ratio of liquid financial assets to household debt, thereby reducing the probability of financial distress and therefore increases consumption and housing investment (Mishkin 2006, 2001).

\subsection{Asset Price Channel}

Similar to the operating ways of balance sheet channel, expansionary monetary policy raises the value of equities. This particular transmission channel rests on Tobin's q theory, which is applied to business investment. Expansionary monetary policy raises price level of stocks. Increase in its stock prices enables the firm to raise additional equity capital by issuing less number of stocks. Importance of asset price channel is further strengthened by Modigliani's life cycle model, according to which increase in financial wealth raises consumption by households (Mishkin 2006, 2001).

\subsection{Exchange Rate Channel}

Monetary policy influences exchange rate through interest rates. An expansionary monetary policy would increase money supply, leading to a fall in interest rate. Under conditions of perfect capital mobility and perfect substitutability of financial assets, capital would flow out and domestic currency would depreciate. Depreciation would make the country's exports more attractive to foreigners; an increase in net exports would result in greater aggregate demand leading to rise in output (Mishkin 2006, 2001).

\subsection{Expectations Channel}

Monetary policy measures have an impact on the economy through their influence on the expectations of economic agents about the future outlook of the economy. In particular, the expectation effects may improve monetary policy transmission channels by shortening reaction lags (Mayes 2004). The expectation channel is more effective, if the central bank has acquired a high degree of credibility established through its past performance.

\section{Fiji's Monetary Policy Measures and Implementation}

The financial sectors in PICs suffer from several weaknesses, which are not very different from those observed in other parts of the developing world (Pill and Pradhan 1995, 1997). These include the following: (i) the underdeveloped nature of banking systems and inefficient payments system; (ii) a limited range and number of securities traded as well as irregular trading; (iii) high transaction costs for banking services; (iv) poorly developed information systems; (v) lack of transparency including inadequacies in the provision of information disclosure requirements and accounting standards; (vi) restrictions on the nature of financial instruments, in regard to issuing and pricing of instruments and trading in these instruments; (vii) inadequate regulatory and prudential supervision of banks and financial markets; and (viii) inappropriate capital controls.

Although Fiji, whose selected key indicators are given in Table 1, is relatively better endowed with human resources than other PICs, with a vibrant private sector, its financial sector institutions are still at early stages of development. Fiji's financial sector comprises three major sectors, namely the banking system, insurance industry and non-bank financial institutions. The banking system had a major setback in 1995/96, when the state-owned National Bank of Fiji (NBF) failed. The failure of NBF, which once accounted for one third of total bank credit, was a wake-up call to the nation. Improvements in bank supervision and regulatory reforms were quickly undertaken (Chandra et al. 2004). Following the restructuring program, the failed bank's operations were taken over by an Australian owned commercial bank. As of 2007, all the five commercial banks (Note 1)are all foreign- owned and are well capitalised. Capital adequacy ratios were maintained above the minimum requirement of $8 \%$, at an average of $12 \%$. Management performance is rated satisfactory in view of strong performance in the components capital adequacy, asset quality, management, earnings and liquidity known as CAMEL [Reserve Bank of Fiji (RBF) 2007a].

Except one bank, which is supervised by a local board, all the foreign-owned commercial banks are supervised from their respective headquarters. However, the general impression has been that they have been conservative with relatively high lending rates. To meet the growing criticisms, banks have shown greater interest in recent years in extending their operations beyond urban areas by running mobile banks in rural areas as well. Sectors to which banks have been lending include private individuals for consumer credit, housing, wholesale, retail, hotels and restaurants and building and construction.

The insurance sector covers life insurance and general insurance. There are two life insurance companies, eight general insurance companies, and five insurance brokers with a large number of insurance agents. Most of the insurance companies have been reported to be well capitalised, meeting their solvency requirements. The bulk of total assets of insurance institutions are invested in government securities as well as in term deposits with commercial banks (RBF 2007a).

There are three non-bank licensed credit institutions (Note 2) (LCI), which cater to the credit needs of private sector in various areas. These include consumer credit, real estate, transport and storage, wholesale, retail, hotels and restaurants, and building and construction. Capital adequacy has remained strong in recent years. In 2007, the capital adequacy 
ratio was $23.7 \%$, compared to the minimum requirement of $10 \%$. In regard to other criteria of asset quality, earnings and liquidity, LCIs have recorded satisfactory position (RBF 2007a).

In addition to these institutions, there is a state-sponsored pension institution, known as Fiji National Provident Fund (FNPF), which collects a stipulated percentage of the salaries of employees in the formal sector matched by a similar contribution from the employers. By an amendment in the Act governing FNPF, domestic workers employed in the informal sector, such as house girls are also covered since 2005. These contributions become payable together with interest to returnable with interest to the members of FNPF upon on their retirement but members have their option to either withdraw lump sum or to take out a pension. The FNPF, as with other institutions, has been restricted to placing their funds overseas. Its investments are concentrated in fixed income securities, the bulk of which is in long-term government and government guaranteed bonds. In recent years FNPF has stepped up its holdings in domestic equities and loans and advances. Short-term funds are kept with commercial banks as deposits of varying duration or invested in government short-term treasury bills.

The government and its agencies, including Fiji Development Bank and Housing Authority are the only source of financial securities. Most of them are short-term treasury bills with limited issue of long-term bonds. Fiji's stock market is at its nascent stage, handling in limited number of privately issued equity stock. There is no secondary market in these securities. Therefore, most of the holders of debt securities hold them until their dates of maturity.

Three years after gaining independence in 1970, Fiji replaced its Currency Board by establishing a Central Monetary Authority (CMA). In 1974, the Fiji dollar was pegged to the US dollar, severing the fixed link with the British pound. In 1975, ending the short-lived link with the US dollar, Fiji pegged its currency to a trade weighted basket of currencies of the major trading partners, an arrangement still continuing till today. The CMA was replaced by Reserve Bank of Fiji (RBF) in 1984, which was set up by an Act of the country's parliament.

The monetary policy measures by RBF until 1988 were more of direct and quantitative in nature. In addition to employment of statutory reserve deposit (SRD) ratio, requiring the commercial banks to hold with monetary authority a stipulated proportion of their deposits mainly meant for prudential purpose, RBF relied on further direct interventions. These included measures under which all licensed financial institutions including commercial banks were required to maintain a minimum of not more than $35 \%$ of deposits and other liabilities in minimum holding of unimpaired liquid assets (ULA) in terms of treasury bills of the government and securities issued by government and by official agencies, which were guaranteed by the government. Aside from imposition of ULA requirement, RBF was fixing credit limits and controlling both deposit and lending rates, along with mandated priority sector lending targets. These quantitative restrictions were gradually relaxed beginning from 1989 and gradually discontinued, as part of financial sector liberalisation programme.

With view to improving its competitiveness, Fiji devalued its currency in 1988 twice by a total $33 \%$. There was another devaluation of the currency by $20 \%$ in 1998 , as a pre-emptive measure in the wake of Asian financial crisis of October 1997. The Fiji dollar continues to be pegged to a basket of the U.S, Australian and New Zealand dollars, the euro, and the Japanese yen. Weights are based on a three-year moving average of Fiji's direction of trade, which are reviewed annually but not published. The exchange rate is currently allowed to move within the existing band from $+/-0.07 \%$, which was once reportedly considered to be expanded to $+/-2 \%$.

The RBF began in 1989 an open-market type of operations in its own short-term debt paper of various maturities, known as RBF Notes, ranging from 91 to 180 days, primarily as a measure towards liquidity management. The RBF Notes are offered for sale through a tendering system, usually twice a week. The yield to maturity of the 91-day RBF Notes has now come to be officially recognised as the policy indicator rate (PIR), signaling the monetary policy stance of RBF. The rate is set in line with RBF's declared monetary policy objectives of low inflation of about 3\% and adequate level of international reserves to cover about 4 months of imports of goods and services. When the actual 91-day rate is not aligned with the policy indicator rate, RBF would exert pressure on the market for short-term funds by selling or redeeming RBF Notes to influence the amounts of funds in their market. The open market operations are conducted to drain out the excess liquidity in the system until the 91-day yield to maturity rate of RBF Note is brought in alignment with the policy indicator interest rate. By maintaining a continuous pressure on the system, the RBF expects to influence the short-term interest rate. The discount rate, at which commercial banks can borrow from RBF known as minimum lending rate (MLR), is linked to PIR. The MLR is normally fixed 50 basis points above PIR. Thus, changes to the PIR are automatically reflected in the MLR.

The PIR is expected to affect other rates in a number of ways. Firstly, changes in PIR are expected to affect money market rate (MMR), which is the inter-bank lending rate and other short-term and capital market interest rates. The primary source of non-bank financial institutions is through issuance of securities in the market. A change in PIR affects the cost of funds, which are raised through the issue of securities and accordingly their lending rates. Change in non-bank lending rates also affect commercial bank rates as they compete in the same market. The RBF Notes provide an alternative investment avenue for investors, as the latter can park their funds in. Therefore, commercial banks would 
find it imperative to offer a competitive rate for attracting/retaining the depositors. Thus, changes in PIR are transmitted to changes in deposit rates. Lending rates are thereafter adjusted in order for banks to maintain the interest rate spread between lending and deposit rates.

The RBF view of on transmission mechanism is no different from the conventional view: transmission of monetary policy is envisaged to be chiefly through interest rate channel (RBF 2007b). There are three main stages identified in the transmission mechanism. : (i) the flow on of changes in short term money market interest rates to other interest rates in the economy, particularly commercial bank lending and deposit rates; (ii) the effects of changes in economic activity; and (iii) the effects of economic activity on inflation and foreign exchange reserves (RBF 2007b).

However, Fiji's success with monetary policy as a tool of economic growth during a 30-year period (1975-2005) is mixed (Dahalan and Jayaraman 2006). Deregulation of the economy and financial sector reforms, which led to adoption of market based PIR did not seem to have had any substantial impact on the economy until 2000, which was hit by political uncertainties. Excess liquidity in the system in the post 1987 coup years due to poor investment climate continued to linger on for the next ten years. The then prevailing environment of low interest rate and low inflation did not however inspire any investor confidence, since political uncertainties posed major stumbling blocks to revival of private investment. With the adoption of a new constitution in 1997, which was followed by the general elections and the installation of an elected government in 1999, the economy appeared to have recovered for while, until there was another coup in May 2000. Fresh elections after the return of democracy in 2001 led to relative stability during the next five years. Fiji witnessed the easing of official trade and aid sanctions by metropolitan powers in the region and a welcome rebound in tourism. In particular, Fiji's economic growth during 2001-2006 was facilitated by an expansionary fiscal policy (D'Hoore 2006).

The prevailing environment of relative political stability during 2001-20005 with favourable factors of low interest rate and low inflation revived consumer confidence as well. Steady rise in private domestic credit, which began with increase in borrowings for consumer durables, spilled over into real estate market as well. There was thus, a revival of private sector credit, which reflected a catching up from the past-depressed levels of investment climate due to political instability. These developments contributed to uninterrupted economic growth during the four years (2001-2006) at an average of $3 \%$, a remarkable phase in Fiji's recent economic history.

The stock of total domestic credit during the early 1970 s was around $22 \%$ of GDP. It rose gradually to $30 \%$ of GDP in the 1980s. During 1980-1984, it was about 32\% of GDP, with credit to private sector being around $25 \%$ of GDP. Consequent to the liberalization of the economy in 1988, as noted earlier, domestic credit comprising both public and private credit rose to new heights. As a proportion of GDP, domestic credit to private sector in 1989 was around $31 \%$ of GDP. However, growth in credit in subsequent years was no longer remarkable, reflecting the general uncertainties, mainly due to political instability, which was responsible for poor private investment climate. After the enactment of a new Constitution in 1997 and the General Elections in 1999, domestic credit recorded new increases. However, a civilian coup in 2000 plunged the nation into new crisis. As a result, domestic credit as a proportion of GDP fell in from $38 \%$ of GDP. With return to democratic government in 2001, normalcy was restored and domestic credit increased again during the next four years to reach a new high at around 47\% of GDP in 2005. Credit to public sector registered increases, as banks and non-bank institutions stepped up investment in government bonds. Credit to private sector also went up, as it recorded increases from 29\% of GDP in 2001 to 39\% of GDP in 2005.

However, "too much of a good thing" had its own problems (Jayaraman and Choong 2007a). Annual budget deficits due to expansionary fiscal policies combined with steady rise in private sector credit during 2001-2006 led to bulging annual current account deficits. As the twin deficits reached unprecedented proportions of GDP (Jayaraman and Choong 2007b), RBF decided to apply brakes by raising PIR from $1.75 \%$ in two stages in late 2005 to reach $2.25 \%$. Again in February 2006, PIR was further raised to 3.25\%; and in June 2006, another increase in PIR was resorted to. This time, it was raised by a full percentage point to $4.25 \%$, the highest in recent years. The MLR was fixed 100 basis points above PIR. Further, during 2006, the statutory deposit ratio (SDR) was also increased from 5\% to $7 \%$ and stringent exchange control measures were also imposed, all with a view to "lowering credit growth and slowing imports" (RBF 2007c).

The results of the restrictive monetary policy pursued since mid 2006 appear to have yielded the intended results. From the second quarter of 2007 onwards, there has been a steady decline in private sector credit growth and fall in imports. Further, as the government also resorted to fiscal adjustments in terms of reducing the number of ministries and departments and non-essential expenditures and freezing vacancies, the current account deficit also got reduced (RBF 2007d).

\section{Modeling and Methodology}

The modeling of monetary policy transmission mechanism in PICs has necessarily to take into consideration of the unique features, which characterize the Pacific island economies. The small sized and undeveloped money and capital markets limit the effectiveness of monetary policy transmission mechanism acting through various channels (Worrell 
2000). In particular, as noted earlier, Fiji's financial sector being shallow with only a few numbers of participants is not deep enough to absorb debt instruments and equities. Furthermore, there is no vibrant secondary market, in which these financial assets could be traded with ease and speed. Thus, there are obvious limitations to the efficient functioning of interest rate channel.

The balance sheet approach presupposes that financial assets are important constituents of firms/consumers portfolios and assumes the existence of convertibility between illiquid (consumer durables) and liquid (financial) assets. Empirical studies in the Caribbean island economies have shown that the markets have not attained such a degree of sophistication that would enable it to function as an efficient conduit for monetary policy (Baksh and Craigwell 1997). A more recent study on Armenia (Dabla-Norris and Floerkemeir 2006) notes that the inability of banks in developing countries to properly assess credit risk, due to both weak risk management expertise and opaque corporate accounting practices, increases banking spreads and reduces the effectiveness of balance sheet channel.

As regards asset price channel mechanism and its variants of Tobin's $q$ theory (valuation of equities) and Modigliani's wealth and consumption model, it has been noted that an important pre-condition, namely presence of financial assets constituting a key component of borrowers' and wealth holders' portfolios does not exist in developing countries. Fiji is no exception. Further, in small economies, as in Fiji, commercial banks dominate the financial sector, since the non-bank financial sector (stock market, debt securities market, mortgage market, insurance market) is still in its infancy. Thus, market financing does not matter, a situation which "largely precludes the asset price channel's working through wealth and income effects" (Dabla-Norris and Floerkemeir 2006: 8)

The exchange rate channel transmission mechanism for its full efficiency presupposes a floating system, which adjusts to capital flows. Since the South Pacific island countries including Fiji, which have independent currencies, follow a fixed exchange rate regime, this particular channel may not operate. The scope for exchange rate channel is further limited in those countries, which still have controls on capital movements and whose financial assets are not perfectly substitutable and desirable from the point of view of foreigners.

\subsection{Monetary Transmission Mechanism in Fiji}

For the purpose of modeling, in Fiji, we define the monetary transmission mechanism as the impact of a change in short term interest rate, on intermediate targets or variables which include money supply, bank credit to private sector, exchange rate and the final objectives, namely output and price level. As for the short-term interest rate, we choose RBF's PIR, the yield to maturity of 91-day RBF Notes, which as noted earlier, represents the monetary stance of the central bank. The second variable chosen is broad money (M2), since the latter is more highly correlated with output (RGDP) and prices, represented by consumer price index (P) than narrow money (M1) (Figure 2). The third variable is bank credit to private sector (CRE), which in recent years has substantially emerged to be of considerable importance. The fourth variable is the nominal exchange rate (E), which is expressed as units of domestic currency per one unit of foreign currency (US dollar) with view to examining the effects of exchange rate changes on output and prices. As noted by Dabla-Norris and Floerkemeir (2006), using the nominal exchange rate as opposed to a real exchange rate makes it easier to distinguish the exchange rate channel from other channels, since we can isolate changes in the nominal exchange rate on real economic activity, separately from changes in prices. Further, since the real exchange rate is already adjusted for changes in prices, using it would make it difficult to isolate price changes (inflation) from exchange rate changes.

For exploring how the monetary shocks affect output and price level, we employ the VAR methodology based on Sims (1980), which has been increasingly employed in recent years in many studies (Dabla-Norris and Floerkemeir 2006, Ramlogan 2004, Morsink and Bayoumi 2001, Ahmed 2002). The chief advantage of using the standard VAR is that only minimal restrictions need to be imposed. Following Berananke and Blinder (1992) and Sims (1992), a VAR with $k$ endogenous variables and $n$ lags can be expressed as:

$\Pi y_{t}=\Pi y_{t-1}+\Pi y_{t-2}+\Pi y_{t-3}+\ldots+\Pi y_{t-n}+\varepsilon_{t}$

where, $y_{t}$ is a $k$ times 1 vector of endogenous variables, $\prod$ is $k$ times $k$ matrix of standard parameters of the endogenous variables and $\varepsilon_{t}$ is $k$ time 1 vectors structural disturbances.

The model is identified using a recursive, contemporaneous system, whereby it is assumed that the structural shocks $\varepsilon_{t}$ is orthogonal and that $\prod$ is lower triangular. If there is no contemporaneous feedback from the non-policy variable to policy variable, it is theoretically sound to place the policy variable first in the recursively ordered system. If the contemporaneous correlation among the shocks in the reduced-form VAR is high (Ahmed 2006), ordering becomes a matter of concern.

\subsection{Data and Choice of Variables}

The model uses quarterly data covering a 17-year period (1990-2006). Data on all variables except real GDP (RGDP) are available on a quarterly time series basis. In the absence of quarterly data on RGDP as well as any data on industrial 
production or any alternative to RGDP, we are constrained to use cubic spline procedure for generating a quarterly RGDP series. The data sources used are Government of Fiji (2007) and RBF (2007a) for real GDP and PIR respectively; and IMF (2007) for M2, CRE, E and P. All six variables duly transformed into logarithmic form are entered into VAR equation in the following order, PIR, M2, CRE, E, RGDP and P.

\section{Empirical Results}

\subsection{Unit Root and Cointegration Tests}

The empirical study begins investigation into the time series properties of each variable employed in the study. A number of unit root tests are used to examine the order of integration of the series under study. The results are shown in Table 3. They include Augmented Dickey-Fuler (ADF) test and Ng-Perron MZ test, which based on the null hypothesis that a unit root exists in the autoregressive representation of the time series. As reported in the table, the variables in equation (1) are non-stationary at level. However, both Augmented Dickey-Fuller (ADF) and Ng and Perron unit root tests indicate that RGDP, M2, CRE, E, PIR and P are integrated of order one.

Using ordinary least squares (OLS) to estimate equation (1) might produce spurious regression or ignore important information about the underlying data-generating processes. However, a long-run relationship between the variables under study can be inferred if the variables are cointegrated; that is, if there exists a linear combination of them that is stationary. The results of the multivariate cointegration analysis following Johansen and Juselius (1990)) are shown in Table 4.

As can be seen from Table 4, both the trace and the maximum eigenvalue statistic point to the existence of long run relationship between real GDP, M2, private credit, exchange rate, interest rate (PIR) and price. Overall, the diagnostics of the VAR indicate Gaussian, uncorrelated and homoscedastic residuals. Only the VAR Jacque-Bera normality joint test is significant at the 5 per cent level. Gonzalo (1994), however, shows that non-fulfillment of the residual normality assumption in the vector autoregression still yield unbiased and consistent estimators.

\subsection{Variance Decomposition of Log Output (RGDP)}

All the variables are then entered in the VAR in log levels giving the system appearance of an unrestricted vector error correction mechanism (Dale and Haldane, 1995). We now proceed to examine the relative strengths of various channels through which monetary pulses are transmitted to output and prices. This is accomplished by carrying out a decomposition of $\log$ RGDP and $\log$ P, with a view to determining the size of the fluctuations in a given variable that are caused by different shocks. We calculate the variance decomposition at forecast horizons of four through 28 quarters. One quarter ahead is the short run and four, eight and 12 quarters represent the medium term, while 20 quarters ahead is the long run. VAR for each variable was estimated, which included 7 lags. The results are reported in Table 5 and Table 6 respectively for $\log$ RGDP and $\log$ P, indicating the percentages of variance of the variable forecast as attributable to each variable at a 28 -quarter horizon. The first column lists the quarters ahead, whereas the second column refers to standard error (SE), which is the forecast error of the variable at different quarters. Variables were ordered in the same way they appear in the Table. That is, the third column refers to PIR, the fourth M2, the fifth CRE, the sixth E, the seventh RGDP and the last P.

Table 5 shows that money channel is the most important channel one amongst all in explaining variation in output, in the short, as well as medium and long terms. In the first quarter, shocks in M2 were the most influential, as they account for 7 percent of the variance in output. Importance of M2 rapidly grows over the next three quarters. In the fourth quarter, shocks in M2 explain 46 percent of variability in output; 74 percent of variability in output in the $8^{\text {th }}$ quarter; and 68 percent of variability in output in the $12^{\text {th }}$ quarter. In the $20^{\text {th }}$ quarter ahead, shocks in $\mathrm{M} 2$ explained nearly three-fourth of variance in output.

Among the other three channels, interest rate channel is well ahead of both exchange rate and credit channels in influencing the variability in output. In the first quarter, shocks in PIR and E respectively account for 3 percent and 2 percent of variability in output, followed by CRE, accounting much less than half a percent of variability in output. However, by the end of short run ( $4^{\text {th }}$ quarter), we find CRE gaining importance over both PIR and E. Shocks in CRE account nearly 4 percent of variability in output, followed closely by E ( 3 percent), whereas shocks in PIR explain output variability only for about one percent. Over the medium term, shocks in PIR emerged to be more responsible for variability in output to a larger extent than $\mathrm{CRE}$ and $\mathrm{E}$. In the $12^{\text {th }}$ quarter, shocks in PIR account for about 7 percent of variability in RGDP, while shocks in CRE and shocks in E respectively account for 2 percent and nearly 4 percent of variability. In the long run, shocks in PIR play a more dominant role than shocks in CRE and $\mathrm{E}$ in explaining the variability in output.

\subsection{Variance Decomposition of Log Price $(P)$}

Table 6 shows the variance decomposition of $\log$ P. The results indicate that in the first quarter, shocks in PIR in the first quarter are the most important influence in explaining the variability in price level. In comparison to M2, CRE and 
E, shocks in PIR in the first quarter ahead, account for 15 percent of variability in price level. In the fourth quarter ahead, shocks in M2 become more influential in explaining the variability in price level. However, beginning from the eighth quarter, influence of PIR declines and shocks in M2 assume a far bigger role. In the medium term., shocks in M2 account for 36 percent variability in price in $8^{\text {th }}$ quarter and 32 percent in $12^{\text {th }}$ quarter. In the long run, shocks in M2 explained nearly 40 percent of variability.

Shocks in PIR have a steady influence on price level, explaining about the 12 percent of variability in price level in the medium term. Thereafter in the long run, shocks in PIR accounted for 11 percent in variability in price level. Exchange rate played an increasingly larger role after its low influence on price level in the first quarter. At the end of the short term, shocks in exchange rate accounted for 5 percent of variability in price level. In the medium term, the influence of exchange rate on price level increased as shocks in E accounted for around 8 percent of variability in price level. In the long run, shocks in $\mathrm{E}$ explained the variability of price level for about 5 percent in $20^{\text {th }}$ quarter. Among all the variables, bank credit to private sector played the least important role. Shocks in CRE explained about 2 percent of variability in price level, and 4 percent in the medium and long run.

\subsection{Correlation Matrix of Reduced-form VAR Residuals}

With view to testing the robustness of the VAR results, which would vary based on different orderings of the variables, we resorted to testing the correlation of reduced-form VAR residuals. Table 7 shows the correlation matrix of the reduced-form VAR residuals based on the ordering of variables, which were entered into VAR. The elements of the correlation matrix between the policy variable, PIR and the rest of the system are very low, indicating that the contemporaneous feedback is not a problem. These correlations suggest that the ordering of the variables in a Choleski decomposition is not of any major concern.

\subsection{Impulse Response Function of Log Output (RGDP) and Log Price (P)}

The extent to which shock in different channels influence both output price can be assessed through impulse response function. The simulation horizon covers 40 quarters. The solid lines are impulse responses and the dotted lines are approximate $90 \%$ error bands that are derived from a bootstrap routine with 2000 replications.

Impulse response function is depicted for a horizon of 40 quarters in Figures 3 and 4, which enables us to trace out the response of output and price to a shock in policy variables. The shock is represented by one standard deviation of the error term in the underlying structural model for the variable. Since all variables are measured in logs, the impulse response functions depict the growth rate relative to the base period when the shock occurred. The first graph in Figure 3 shows the response of output to shock in PIR (tightening of monetary stance) represented by one standard deviation of monetary aggregate. A one-standard deviation shock to PIR dampens the growth in RGDP, literally reducing it to zero until the fifth quarter and thereafter has a negative impact on output in the medium term.

Shock in monetary aggregate (M2) has a positive impact on output right from the first quarter reaching the peak between the seventh and eighth quarter and thereafter gently declining in the tenth quarter. After that, the positive influence of shock of M2 on the growth of RGDP increases. Similarly, the shock to credit (CRE) has positive impact on real GDP. The peak is reached after the fourth quarter. Thereafter, the effect gently declines to reach zero after the seventh quarter and becomes negative. Overall, the impact of shock to credit on real output is not strong in the long-term. A shock to exchange rate (E) produces negative impact on real GDP throughout the period. It is thus clear from Figure 3 that shocks to money, amongst all the policy variables, have the largest impact on output followed by shocks to credit and exchange rate.

In regard to price (Figure 4), one-standard deviation shock to interest rate (PIR) has a negative impact on price until the third quarter, which gets stabilized to exercise a positive effect on price for a while until fifth quarter and thereafter gently rises. One-standard deviation shock to the money has a positive effect on the price. The effect gradually increases and reaches the peak in the twelfth quarter. Thereafter, it shows a decreasing trend but begins to stabilize after four quarters. However, the effect remains substantial throughout 24 quarters or six years. This indicates that shocks to monetary aggregate have greater impact on prices in the long run.

Over a period of first eight quarters, the impact shock to credit on prices remains negative. After some fluctuations in the next few quarters, the impact becomes positive, and stabilizes afterward in the long run. A shock to exchange rate has a much more dampening effect on price level throughout the period. Thus, inferences drawn from variance decomposition analysis are confirmed by impulse response analysis as well (Figures 3 and 4).

\section{Summary and Conclusions}

This paper undertook an empirical investigation of monetary policy transmission mechanism in Fiji. As part of financial sector reforms, in 1998 Fiji's central bank switched on to the use of indirect instruments by moving away from direct intervention measures, which in the past included ceilings on lending rates and fixing deposit rates as well as quantitative controls on credit to priority sectors. The RBF presently aims at influencing the short-term interest rate 
through open market type operations in its own paper, known as RBF Notes. The yield to maturity of 91-day RBF Note is now known as the policy indicator interest rate (PIR). Changes in PIR signify changes in monetary stance of RBF.

Since Fiji's financial sector is small with an underdeveloped primary market along with near absence of a significant secondary market for government securities and central bank papers, the money market is not efficient for transmitting monetary pulses emitted through changes in PIR. However, RBF's open market operations in its own paper result in changes in nonborrowable reserves, which in their turn alter banks' reserves, monetary base and finally money supply. Thus, money channel becomes an important conduit of monetary policy shocks. Changes in broad money supply impact bank's balance sheets and banks' liabilities are duly transformed into assets through bank credit to private sector.

Focusing on four channels of transmission, PIR, M2, bank credit to private sector, and nominal exchange rate, our empirical investigation covered a 17-year period (1990-2006). Using quarterly data and employing variance decomposition and impulse response analyses, our investigation shows that money channel has been the most important one amongst all the transmission mechanisms studied.

In the context of the current under-developed status of Fiji's money market, the results are not surprising: interest rate channel is not the principal conduit of monetary policy shocks. The study finding that money channel is the most dominant channel in Fiji is similar to the findings documented by studies on other developing countries. In the developing countries, including PICs, savers as investors have a limited portfolio choice and hence tend to depend on the banking system. Since Fiji's financial sector development is still at an evolving stage, it is only reasonable to expect that with the emergence of various financial instruments, monetary policy transmission mechanism would undergo changes in the future.

\section{References}

Ahmed, S. (2003). Sources of economic fluctuations in Latin America and implications for choice of exchange rate regimes. Journal of Development Economics, 72, 181-202.

Asian Development Bank (ADB) (2007). Key Indicators of Developing Asian and Pacific Countries, Manila: ADB.

Baksh, S. and Craigwell, R.C. (1997). The monetary transmission mechanism in small open economies: A case study of Barbados. Savings and Development, XXI, 179-193.

Bernanke, B.S. (1986). Alternative explanations of money-income correlation. Working Paper No. 184 Washington, D.C.: National Bureau of Economic Research.

Bernanke, B.S and Blinder, A.S. (1988). Is it money, or credit or both or neither? Credit, Money and Aggregate Demand. American Economic Review, 78, 435-439.

Bernanke, B.S and Blinder, A.S. (1992). The federal funds rate and the channels of monetary transmission. American Economic Review, 82, 901-921.

Chandra, A., Jayaraman, T.K. and Waqabaka, F. (2004). Reforms in banking supervision in Fiji: A review of progress. Pacific Economic Bulletin, 19, 102-114.

Dabla-Norris, E. and Floerkemeir, H. (2006). Transmission mechanism of monetary policy in Armenia. Working Paper WP/06/248, Washington, D. C.: International Monetary Fund.

Dahalan, J. and Jayaraman, T.K. (2006). Monetary and fiscal policies in Fiji: A test of effectiveness. Pacific Economic Bulletin, 21, 94-102.

Dale, S. and Haldane, A.G. (1995). Interest rates and the channels of monetary policy transmission: Some sectoral estimates. European Economic Review, 39, 1611-1626.

D’Hoore, A. (2006). Fiji. Chapter 8 in C. Brown (ed.) Pacific Island Economies. Washington, D.C.: IMF.

Engel, R.F. and Granger, C.W.J. (1987). Cointegration and error correction: Representation, estimation and testing. Econometrica, 55, 251-276.

Government of Fiji (2007). Key Statistics December 2006, Suva; Fiji Islands Bureau of Statistics.

Guender, A.V. (1998). Is there a bank lending channel of monetary policy in New Zealand? The Economic Record, 7, 243-265

International Monetary Fund (IMF) (2004). Monetary Policy Implementation at Different Stages of Market Development: Country Cases and Appendices-Supplementary Information, Washington, D.C.: IMF

International Monetary Fund (IMF) (2007). International Financial Statistics, July 2007, CD-ROM, Washington, D.C: IMF.

Jayaraman, T.K. and Choong, C.K. (2007a). Financial sector development and private sector credit boom in Fiji: 
Implications of private credit. Asia Pacific Economic Journal, 5, 1-20.

Jayaraman, T. K. and Choong, C.K. (2007b). Is the Twin Deficit Hypothesis relevant to Fiji. Journal of Fijian Studies, $5,1-27$.

Johansen, S. (1988). Statistical analysis of cointegrating vectors. Journal of Economic Dynamics and Control, 12, 231-254.

Johansen, S and Juselius, K. (1990). Maximum likelihood estimation and inference on cointegration with applications to the demand for money. Oxford Bulletin of Economics and Statistics, 52, 169-210.

Kashyap, A.K. and Stein, J.C. (1994). The impact of monetary policy on bank balance sheets. NBER Working Paper 4821, Cambridge, Mass: National Bureau of Economic Research.

Kashyap, A.K., Stein, J.C. and Wilcox, D.W. (1993). Monetary policy and credit conditions: Evidence from the composition of external finance. American Economic Review, 83(1), 78-98.

Katafono, R. (2000). The relationship between monetary aggregates, inflation and output in Fiji. Working Paper No.00/02, Suva: Reserve Bank of Fiji

King (1986). Monetary transmission-through bank loans or bank liabilities. Journal of Money, Credit and Banking, 18, 290-333.

Mayes, D. (2004). The Monetary Transmission Mechanism in the Baltic States. Talinin: Bank of Estonia.

Meltzer, A.H. (1995). Monetary, credit and other transmission process. Journal of Economic Perspectives, 9, 3-10

Mishkin , F. (1996). "The Channels of Monetary Policy Transmission: Lessons for Monetary Policy", NBER Working Paper 5464, Cambridge, Mass: National Bureau of Economic Research.

Mishkin. F. (2001). The Transmission Mechanism and the Role of Asset Prices", NBER Working Paper 8617, Cambridge, Mass: National Bureau of Economic Research.

Mishkin, F. (2006). The Economics of Money, Banking and Financial Markets. $8^{\text {th }}$ Edition, New York: Addison Wesley.

Morsink, J. and Bayoumi, T. (2001). A Peep in inside the Black Box: Monetary Transmission in Japan. IMF Staff Papers, 48(1), 22-57.

Morris, C.S. and Sellon, G.H. (1995). Bank lending and monetary policy: Evidence on a credit channel. Economic Review, Quarter II, 59-95

Pierce, D.G. and Tysome, P.J. (1985). Monetary Economics: Theories, Evidence and Policy, London: Butterworth.

Pill, H. and Pradhan, M. (1995). Financial indicators and fianacial change in Africa and Asia. IMF Working Paper, No.95/123, Washington, D.C.: IMF.

Pill, H. and Pradhan, M. (1997). Financial liberalisation in Africa. Finance and Development, June, 7-10

Ramey, V. (1993). How important is the credit channel in the transmission of monetary policy? Carnegie-Rochester Conference Series on Public Policy, 39, 1-46.

Ramlogan, C. (2004). The transmission mechanism of monetary policy: Evidence from the Caribbean. Journal of Economic Studies, 34, 435-447.

Reserve Bank of Fiji (RBF) (2007a). RBF Annual Report and Accounts 2006, Suva: RBF.

Reserve Bank of Fiji (RBF) (2007b). The Monetary Policy Transmission Mechanism. [Online] Available: www.rbf.gov.fj (August 19, 2007).

Reserve Bank of Fiji (RBF) (2007c). Monetary Policy Statement May 2007, Suva: RBF.

Reserve Bank of Fiji (RBF) (2007d). Quarterly Review June 2007, Suva: RBF.

Romer, C. and Romer, D. (1990). New evidence on the monetary transmission mechanism. Brookings Papers on Economic Activity, 1, 149-198.

Sims, C. (1980). Macroeconomics and reality. Econometrica, 48, 1-48.

Sims, C. (1992). Interpreting the macroeconomic time series fact: The facts of monetary policy. European Economic Review, 36, 975-101.

Taylor, J.B. (1995). The monetary transmission mechanism: an empirical framework. Journal of Economic Perspectives, 9(Fall), 11-26.

UNESCAP (2007). Social and Economic Survey of Asia and Pacific, 2004. Bangkok: UNESCAP. 
Waqabaca, C. (2000). Financial sector development and reform in Fiji. Working Paper No 00/05, Suva: Reserve Bank of Fiji

Waqabaca, C. and Morling, S. (1999). The conduct of monetary policy in Fiji. Working Paper No99/01, Suva: Reserve Bank of Fiji.

Worrell, D. (2000). Monetary and fiscal coordination in small open economies. Working Paper WP/00/56, Washington, D.C.: IMF.

\section{Notes}

Note 1. These are: Australian and New Zealand Banking Group Limited (ANZ), Westpac Banking Corporation (Westpac), Bank of Baroda (BOB), Colonial National Bank and Bank of South Pacific.

Note 2. LCIs include Merchant Finance Investment Company Limited, Credit Corporation (Fiji) Limited and Home Finance Company Limited.

Table 1. Fiji: General key indicators

\begin{tabular}{|l|r|}
\hline Surface Area (sq km) & 18,270 \\
\hline Population (2005) & 835,000 \\
\hline Total GDP at current prices (US \$ million) 2002 & 1,750 \\
\hline Per capita GDP in current price (US\$) & 2,360 \\
\hline Human Development Index (Rank) 2002 & 81 \\
\hline Aid per capita (US\$) 2002 & 41 \\
\hline Aid per capita (\% of GDP) 2002 & 1.8 \\
\hline Openness:(\% of Export \& Imports of GDP) 2005 & 88 \\
\hline
\end{tabular}

Source: ADB (2007), UNESCAP (2007)

Table 2. Growth rates and monetary statistics in Fiji

\begin{tabular}{|l|c|c|c|c|c|c|c|c|c|}
\hline & $\begin{array}{c}\text { Growth } \\
\text { Rate } \\
\text { (\%) }\end{array}$ & $\begin{array}{c}\text { M1 } \\
\text { (F\$ } \\
\text { Million) }\end{array}$ & $\begin{array}{c}\text { M2 } \\
\text { (F\$ } \\
\text { Million) }\end{array}$ & $\begin{array}{c}\text { M1 } \\
\text { (\% of } \\
\text { GDP) }\end{array}$ & $\begin{array}{c}\text { M2 } \\
\text { (\% of } \\
\text { GDP) }\end{array}$ & $\begin{array}{c}\text { CPI } \\
\text { (Index) }\end{array}$ & $\begin{array}{c}\text { RBF } \\
\text { Indicator } \\
\text { Rate } \\
\text { (\%) }\end{array}$ & $\begin{array}{c}\text { Money } \\
\text { Market } \\
\text { Rate } \\
\text { (\%) }\end{array}$ & $\begin{array}{c}\text { Nominal } \\
\text { Exchange } \\
\text { Rate } \\
\text { (Index) }\end{array}$ \\
\hline $\begin{array}{l}\text { 1985-1989 } \\
\text { (Average) }\end{array}$ & 0.4 & 276.0 & 810.0 & 15.7 & 46.2 & 57.4 & NA & 5.2 & 139.6 \\
\hline $\begin{array}{l}\text { 1990-1994 } \\
\text { (Average) }\end{array}$ & 2.9 & 331.4 & 1274.0 & 14.4 & 55.2 & 84.3 & NA & 3.4 & 117.3 \\
\hline $\begin{array}{l}\mathbf{1 9 9 5 - 1 9 9 9} \\
\text { (Average) }\end{array}$ & 2.8 & 500.4 & 1454.2 & 15.6 & 46.2 & 98.8 & 2.10 & 2.2 & 111.7 \\
\hline $\mathbf{2 0 0 0}$ & -1.7 & 593.7 & 1513.8 & 16.5 & 42.2 & 100.0 & 2.30 & 1.0 & 100.0 \\
\hline $\mathbf{2 0 0 1}$ & 2.0 & 620.9 & 1467.8 & 16.4 & 38.8 & 102.3 & 1.25 & 1.0 & 99.4 \\
\hline $\mathbf{2 0 0 2}$ & 3.2 & 712.0 & 1583.0 & 17.7 & 39.3 & 106.0 & 1.25 & 0.9 & 101.1 \\
\hline $\mathbf{2 0 0 3}$ & 1.1 & 900.6 & 1980.4 & 20.6 & 45.2 & 109.6 & 1.19 & 0.9 & 106.0 \\
\hline $\mathbf{2 0 0 4}$ & 5.3 & 1018.0 & 1926.0 & 21.5 & 40.7 & 113.2 & 1.75 & 0.9 & 107.8 \\
\hline $\mathbf{2 0 0 5}$ & 0.7 & 1197.0 & 2241.0 & 23.6 & 44.2 & 115.7 & 2.25 & 2.1 & 107.7 \\
\hline $\mathbf{2 0 0 6}$ & 2.0 & 1142.4 & 3012.8 & 21.3 & 44.2 & 118.8 & 4.25 & 5.3 & 105.9 \\
\hline
\end{tabular}

Sources: Government of Fiji (2006); ADB (2007); IMF (2007)

Authors' calculations. 
Table 3. Unit root tests

\begin{tabular}{|l|c|c|c|c|}
\hline \multirow{2}{*}{ Variable } & \multicolumn{2}{|c|}{ ADF Test } & \multicolumn{2}{c|}{ Ng and Perron MZ Test } \\
\cline { 2 - 5 } & $\begin{array}{c}\text { Level (Constant } \\
\text { with Trend) }\end{array}$ & $\begin{array}{c}\text { First Difference } \\
\text { (Constant } \\
\text { without Trend) }\end{array}$ & $\begin{array}{c}\text { Level (Constant } \\
\text { with Trend) }\end{array}$ & $\begin{array}{c}\text { First Difference } \\
\text { (Constant } \\
\text { without Trend) }\end{array}$ \\
\hline PIR & $-1.38(0)$ & $-5.83^{* *}(1)$ & $-7.28(0)$ & $-42.57^{* *}(1)$ \\
\hline CRE & $2.96(0)$ & $-4.58^{* *}(0)$ & $-2.22(1)$ & $-25.11^{* *}(1)$ \\
\hline M2 & $2.25(1)$ & $-4.66^{* *}(0)$ & $1.01(0)$ & $-46.34^{* *}(0)$ \\
\hline E & $-1.93(0)$ & $-8.22^{* *}(0)$ & $-7.11(0)$ & $-33.98^{* *}(0)$ \\
\hline RGDP & $-0.25(10)$ & $-2.97^{* *}(0)$ & $0.28(10)$ & $-36.32^{* *}(1)$ \\
\hline P & $-3.14(3)$ & $-7.49^{* *}(1)$ & $-15.18(0)$ & $-61.76^{* *}(1)$ \\
\hline
\end{tabular}

Notes: The ADF critical value at 5\% level is -2.9640 and -3.5629 for constant without trend and constant with trend regressions, respectively. These critical values are based on Mckinnon. The optimal lag is selected on the basis of Akaike Information Criterion (AIC). The Ng and Perron critical value is based on $\mathrm{Ng}$ and Perron (2001) critical value and the optimal lag is selected based on Spectral GLS-detrended AR based on SIC. The null hypothesis of the test is: a series has a unit root. The asterisk ** denotes the rejection of the null hypothesis at the 5\% level of significance. The figures in brackets denote number of lags.

Table 4. Results of Johansen and Juselius Multivariate Procedure (VAR with 2 lags)

\begin{tabular}{|c|c|c|c|c|}
\hline \multicolumn{5}{|c|}{$\begin{array}{l}\text { Variables: RGDP M2 CRE E PIR P } \\
\text { Sample Period: 1990Q1-2006Q4 (68 observations) }\end{array}$} \\
\hline \multirow[t]{2}{*}{ Hypothesis } & \multicolumn{2}{|c|}{ Maximum Eigenvalue } & \multicolumn{2}{|c|}{ Trace } \\
\hline & Test Statistic & $95 \%$ & Test Statistic & $95 \%$ \\
\hline $\mathrm{P}=0$ & $56.47 * *$ & 44.50 & $152.21 * *$ & 117.71 \\
\hline $\mathrm{P} \leq 1$ & 37.71 & 38.33 & $95.73 * *$ & 88.80 \\
\hline $\mathrm{P} \leq 2$ & 28.41 & 32.12 & 58.02 & 63.88 \\
\hline $\mathrm{P} \leq 3$ & 16.78 & 25.82 & 29.61 & 42.92 \\
\hline $\mathrm{P} \leq 4$ & 9.34 & 19.39 & 12.83 & 25.87 \\
\hline $\mathrm{P} \leq 5$ & 3.49 & 12.52 & 3.49 & 12.52 \\
\hline \multicolumn{5}{|c|}{ Diagnostic Checking } \\
\hline \multicolumn{5}{|c|}{ VAR Residual Serial Correlation LM Tests } \\
\hline Lags & \multicolumn{2}{|c|}{ LM-Stat } & & \\
\hline 3 & \multicolumn{2}{|c|}{$32.39[0.6408]$} & & \\
\hline 4 & \multicolumn{2}{|c|}{$46.32[0.1163]$} & & \\
\hline 5 & \multicolumn{2}{|c|}{$23.07[0.9530]$} & & \\
\hline
\end{tabular}

Notes: $* *$ indicates significant at 5 per cent level.

VAR specification: lag-length 1.

Critical values of trace and maximum eigenvalue according to Osterwald-Lenum (1992).

Values in brackets are probability value of the test statistics.

Jarque-Bera test, null hypothesis: normal residuals, Breusch-Godfrey Serial Correlation LM Tests, null hypothesis: no autocorrelation. 
Table 5. Variance Decomposition of Log Output (RGDP)

\begin{tabular}{|c|c|c|c|c|c|c|c|}
\hline $\begin{array}{c}\text { Quarters } \\
\text { ahead }\end{array}$ & S.E. & PIR & M2 & CRE & E & P & RGDP \\
\hline 1 & 0.6723 & 2.6143 & 7.2991 & 0.0594 & 2.4554 & 0.0000 & 87.5718 \\
\hline 4 & 7.0035 & 1.3608 & 45.5884 & 3.7260 & 3.4078 & 11.3062 & 34.6107 \\
\hline 8 & 16.7886 & 4.7353 & 73.9038 & 2.1336 & 1.9747 & 8.1981 & 9.0545 \\
\hline 12 & 18.1584 & 6.5936 & 68.4588 & 2.4461 & 3.8545 & 7.1396 & 11.5075 \\
\hline 16 & 23.5872 & 7.2570 & 67.2580 & 2.2019 & 2.3275 & 11.4065 & 9.5492 \\
\hline 20 & 32.6488 & 5.0245 & 73.9577 & 2.1902 & 2.6506 & 9.7437 & 6.4334 \\
\hline 24 & 37.1978 & 7.7880 & 65.7485 & 3.3002 & 4.9341 & 12.7793 & 5.4499 \\
\hline 28 & 41.5988 & 7.8691 & 62.5871 & 2.8430 & 4.9051 & 16.5480 & 5.2477 \\
\hline
\end{tabular}

Cholesky Ordering: PIR CRE M2 E RGDP P

Table 6. Variance Decomposition of Price (P)

\begin{tabular}{|c|c|c|c|c|c|c|c|}
\hline $\begin{array}{c}\text { Quarters } \\
\text { ahead }\end{array}$ & S.E. & PIR & M2 & CRE & E & P & RGDP \\
\hline 1 & 0.8844 & 15.0286 & 12.7376 & 0.9480 & 0.1704 & 69.4644 & 1.6510 \\
\hline 4 & 1.3955 & 13.0018 & 31.1558 & 2.2386 & 5.2596 & 47.1677 & 1.1765 \\
\hline 8 & 1.7212 & 12.5798 & 36.3445 & 4.4307 & 7.5775 & 37.8232 & 1.2443 \\
\hline 12 & 1.9556 & 13.9073 & 31.6278 & 4.6123 & 7.7383 & 37.1247 & 4.9895 \\
\hline 16 & 2.4169 & 10.3144 & 38.2205 & 4.0009 & 5.1654 & 34.1175 & 8.1814 \\
\hline 20 & 2.5440 & 11.7999 & 38.9824 & 4.0222 & 5.1048 & 32.5929 & 7.4978 \\
\hline 24 & 2.7592 & 11.8518 & 41.5544 & 3.9850 & 7.1328 & 28.5335 & 6.9425 \\
\hline 28 & 3.0252 & 17.2349 & 35.7977 & 5.7352 & 9.5568 & 25.7190 & 5.9564 \\
\hline
\end{tabular}

Cholesky Ordering: PIR CRE M2 E RGDP P

Table 7. Correlation matrix of reduced-form residuals

\begin{tabular}{|c|c|c|c|c|c|c|}
\hline & RGDP & M2 & CRE & PIR & $\mathrm{E}$ & $\mathrm{P}$ \\
\hline RGDP & 1 & 0.0758 & -0.1263 & 0.0635 & -0.0333 & 0.1984 \\
\hline M2 & & 1 & 0.0994 & -0.1540 & 0.0521 & -0.0811 \\
\hline CRE & & & 1 & 0.2236 & -0.0717 & 0.0190 \\
\hline PIR & & & & 1 & 0.0044 & -0.2676 \\
\hline $\mathrm{E}$ & & & & & 1 & -0.3167 \\
\hline$P$ & & & & & & 1 \\
\hline
\end{tabular}




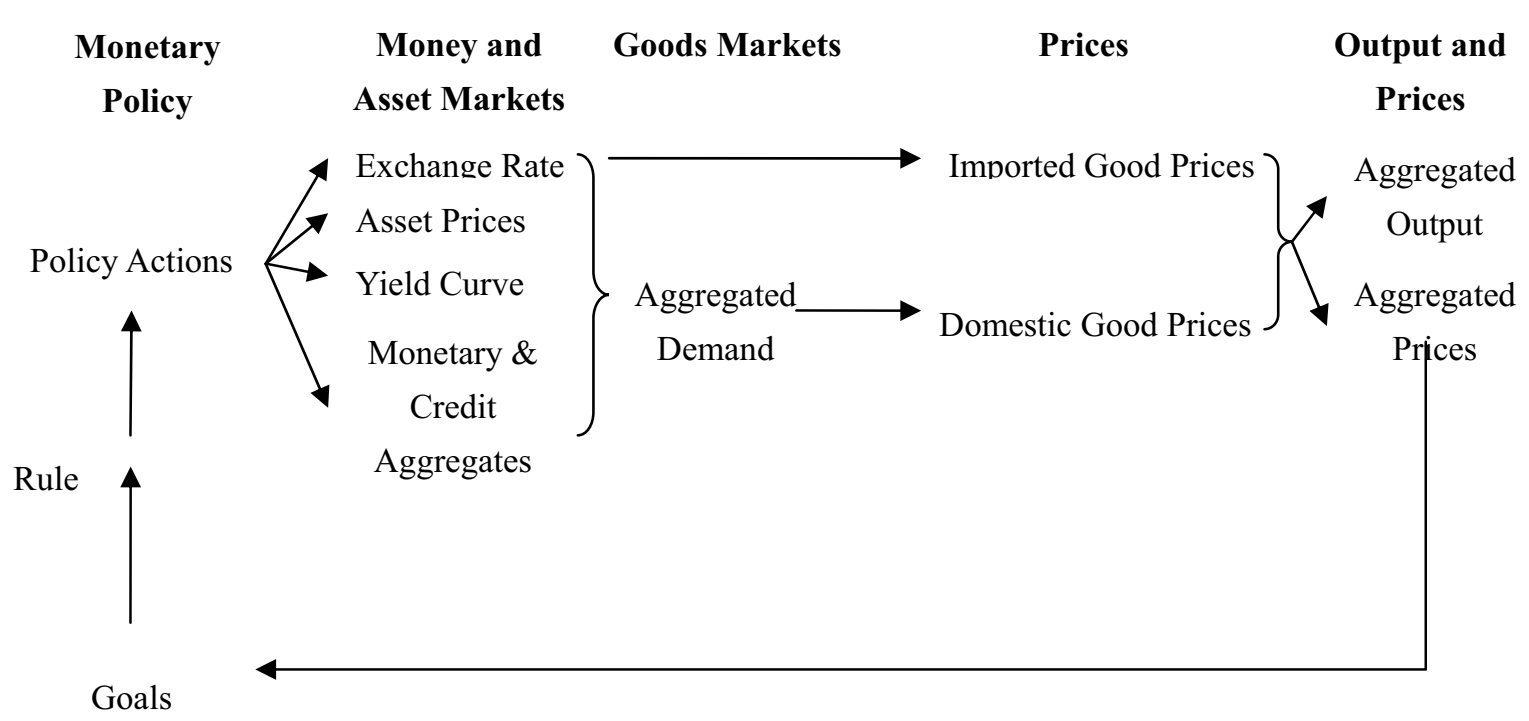

Source: IMF (2004)

Figure 1. Stylized representation of the channels of transmission

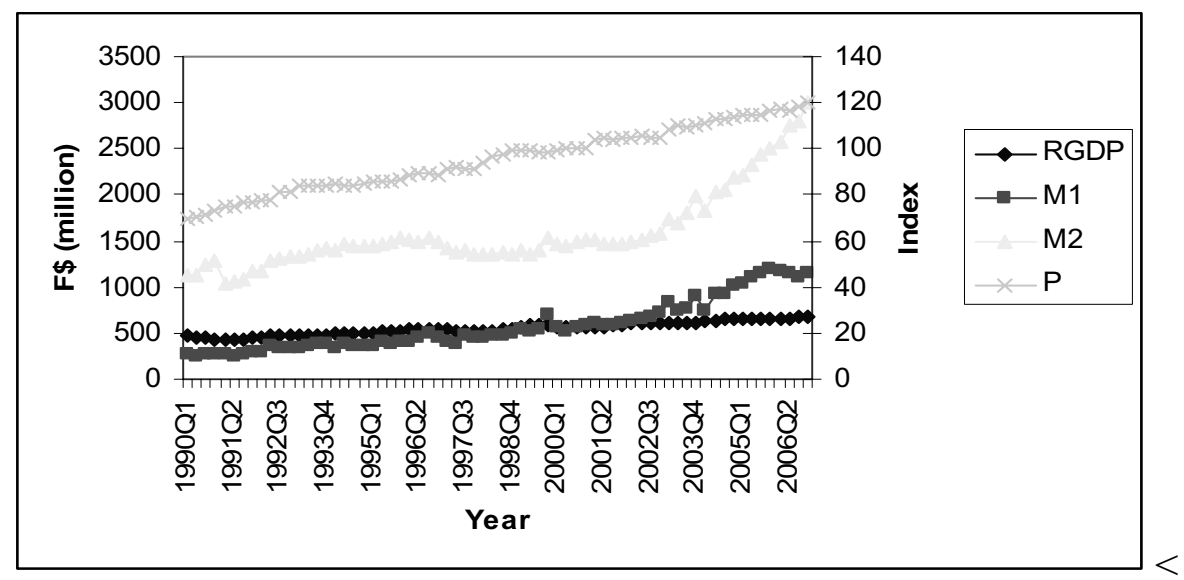

Figure 2. Graph of Movements in M1, M2, P and RGDP

Source: International Monetary Fund, International Financial Statistics, various issues. 
Response to Cholesky One S.D. Innovations \pm 2 S.E.
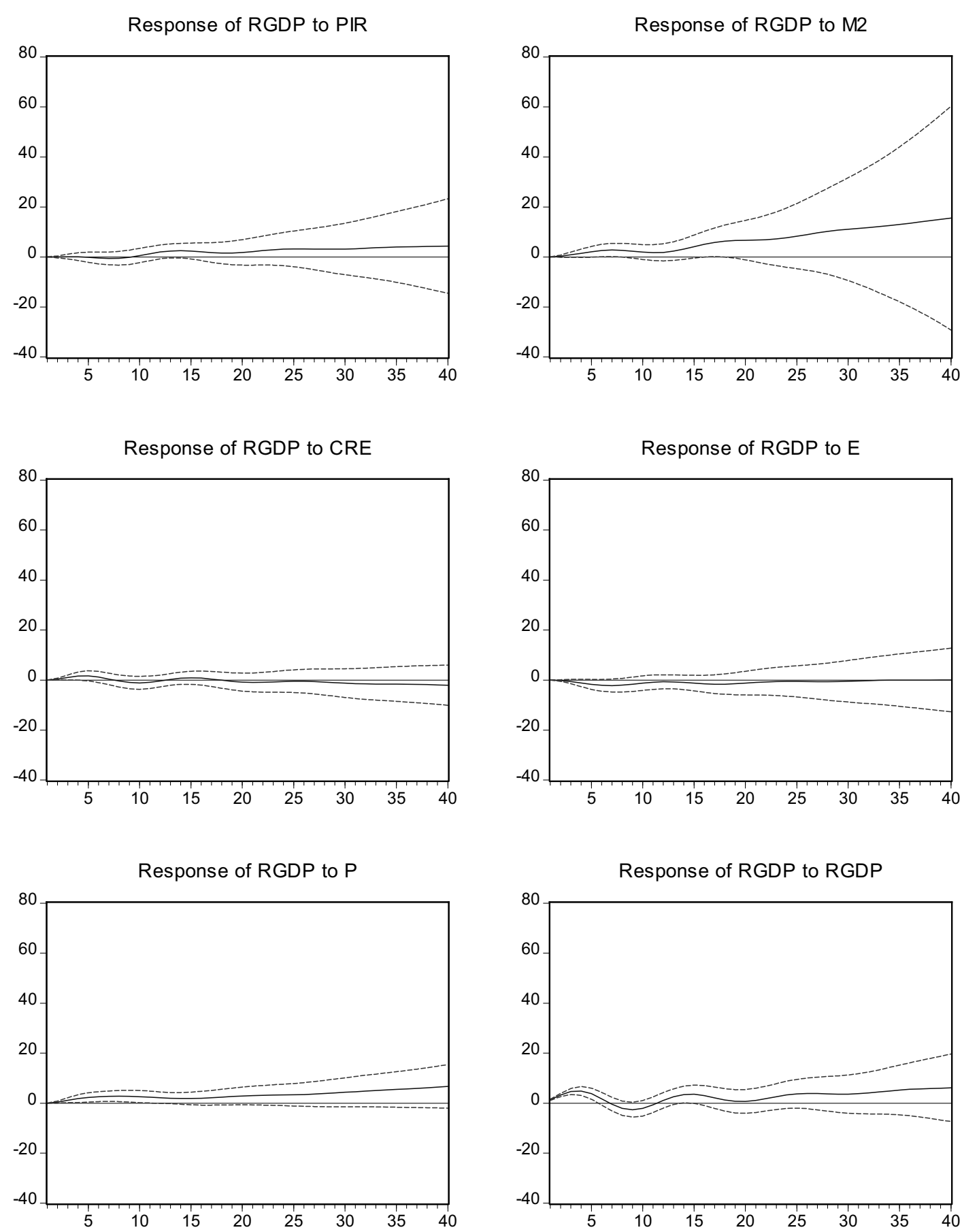

Figure 3. Response of log Output (RGDP) in Fiji 
Response to Cholesky One S.D. Innovations \pm 2 S.E.

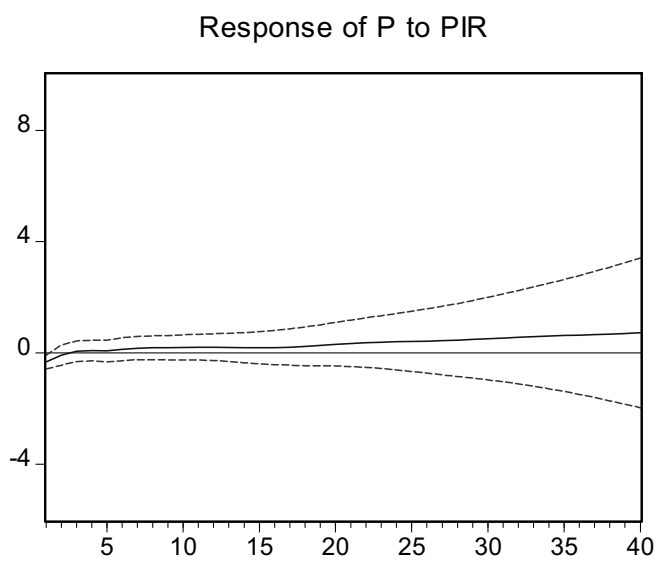

Response of $\mathrm{P}$ to $\mathrm{M} 2$

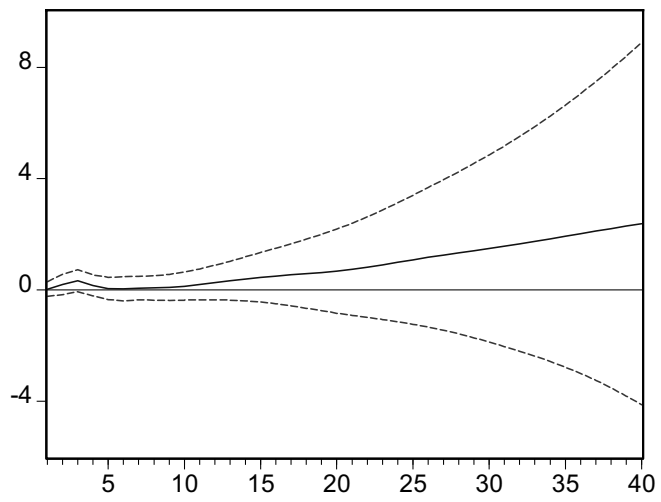

Response of $\mathrm{P}$ to $\mathrm{CRE}$

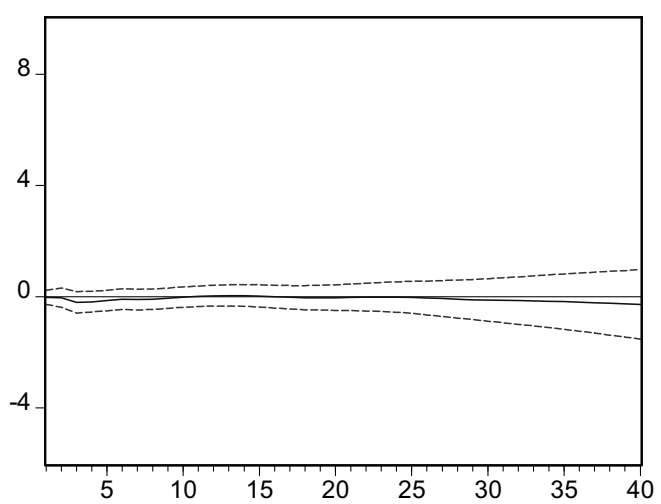

Response of $\mathrm{P}$ to $\mathrm{E}$

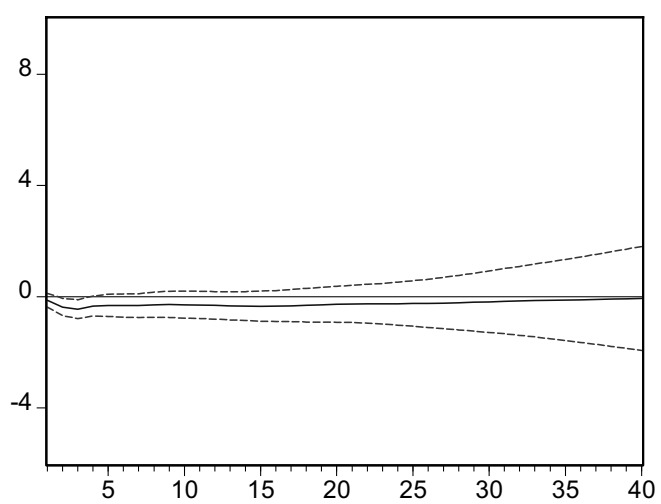

Response of $\mathrm{P}$ to $\mathrm{P}$

Response of $P$ to RGDP
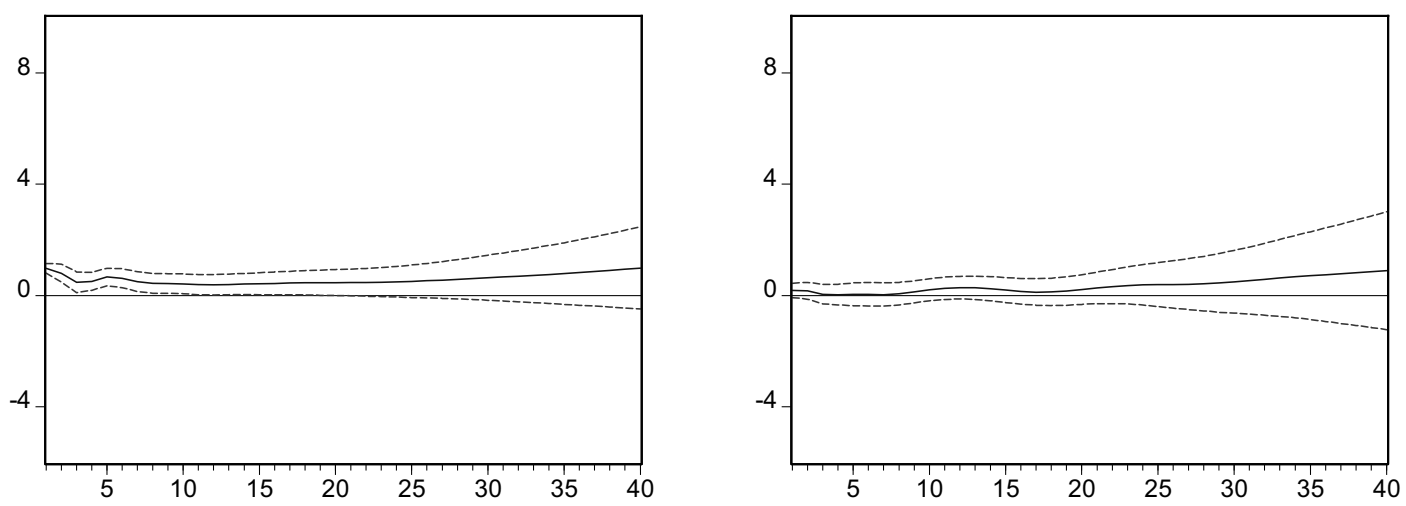

Figure 4. Response of Price (P) in Fiji 